\title{
505 AND ALL THAT- THE DEFENDANT'S DILEMMA
}

\author{
Peter Jaszi* \\ I

\section{INTRODUCTION}

It seems likely that, over the years, no provision of the American copyright law has exceeded that now codified as 17 U.S.C. section 505 in influencing the actual conduct of infringement litigation. Language authorizing discretionary awards of attorney's fees in favor of "prevailing parties" first materialized in the Copyright Act of 1909,1 and was carried forward, without substantive change and indeed with little discussion of any kind, into the Copyright Act of $1976 .^{2}$ So it is somewhat surprising that neither the rationale of this provision

Copyright $\odot 1992$ by Peter Jaszi

* Professor of Law, The American University, Washington College of Law.

Preparation of this article was generously supported by my institution's Summer Research Grant program.

1. Section 40 of the Act provided that

[i]n all actions, suits, or proceedings under this title, except when brought by or against the

United States or any officer thereof, full costs shall be allowed, and the court may award to

the prevailing party a reasonable attorney's fee as part of the costs.

Copyright Act, Pub L No 349, 35 Stat 1075 (1909).

Although the entire provision was a novelty in American copyright, it attracted little critical attention during the deliberations over the 1909 Act. A lone historically minded witness did warn the Congress that "[y]ou have made provision by which the recovery of costs shall be such as never have appeared in any federal court before." Common Law Rights as Applied to Copyright, Hearing before the Subcommittee on Copyright of the House Committee on Patents, 60th Cong, 2d Sess 31 (Committee Print 1909) (comments of Robert Parkinson, Esq.). This cautionary comment, however, refers to the section as a whole, rather than to its language on attorney's fees in particular. Notably, pre-1908 drafts of the copyright revision legislation made no specific provision for the inclusion of fees in accounting of costs. See, for example, The Copyright Bill, S 6630, HR 19853, 59th Cong, 1st Sess 1 (1906), in Copyright Office Bulletin No 12 at 56 (Govt Printing Office, 1906) (Section 35 of original bill, providing "[ $\mathrm{t}]$ hat in all recoveries under this Act full costs shall be allowed"). After the final language of the section was proposed in 1908, see Revision of Copyright Laws, Hearings before the Committees on Patents, 60th Cong, lst Sess 1 (1908), the new provisions for the allowance of attorney's fees generated no discussion whatsoever, and the entire section was treated as essentially noncontroversial. Id at 109 (colloquy between Senator Smoot (Chairman), Representatives Currier, and W.A. Livingstone).

2. In the series of background studies that kicked off the revision process, attorney's fees receive only a lick and a polish, with no discussion of the philosophy underlying the relevant statutory provisions. Quoting from the 1917 edition of Weil on Copyright, the most directly relevant study noted simply that because "expense of any litigation is considerable [so that] it may not pay a party to defend rights, even if valid, a situation opposed to justice." Therefore, "[i]t is increasingly recognized that the person who forces another to engage counsel either to vindicate, or defend, a right should bear the expense of such engagement and not his successful opponent." Notably, perhaps, this passage treats the attorney's fee provisions as of equal potential applicability to plaintiffs and defendants. William S. Strauss, The Damages Provisions of the Copyright Law, Copyright Revision Study No 22, 86th Cong, 2d Sess 36 (1960). An equally "even-handed" approach characterizes the 1961 Register's Report on Copyright Law Revision: "[ $t$ ]he costs involved 
nor the various questions that arise in its application have been the subject of sustained inquiry. Although discussions of the philosophy and practicalities of awarding attorney's fees in copyright cases do appear in individual court decisions, these tend to be mutually-if not internally-inconsistent. And while recognizing the confusion surrounding the question of when attorney's fees should be awarded, treatise writers have done little to dissipate it. ${ }^{3}$

Section 505,4 as conventionally interpreted, operates to encourage litigation by copyright plaintiffs; those same interpretations, however, have the dysfunctional effect of chilling the vigorous assertion of various defenses to claims of infringement. It may not be too much to suggest that the continuing health of American copyright law depends, in significant part, on our success in righting this skewed balance. Whether that reconsideration takes the form of additional case law development or of new legislation, it is crucially overdue.

II

\section{Disincentive Effect on Defendants}

In assessing the disincentive effect of attorney's fees awards where defendants are concerned, I take as my paradigm the case of an unauthorized user of material from a copyrighted work who has made knowing, intentional

in an infringement action are usually relatively small. But the prosecution or defense of a copyright suit may entail a good deal of work and expense, and an award of attorney's fees can be substantial." Report of the Register of Copyrights on the General Revision of the Copyright Laws, 87th Cong, 1st Sess 30 (1961) (supporting the retention of provisions allowing discretionary awards of attorney's fees in new legislation).

Although private parties proposed that the attorney's fees provisions be amended to make awards mandatory in case of the infringement of registered works, see Copyright Law Revision, Part IV: Further Panel Discussion and Comments on the Preliminary Draft for Revised U.S. Copyright Law, 86th Cong, 2d Sess 69 (1964) (letter from Ernest S. Myers noted), the language of the Preliminary Draft was to be carried forward, without substantial change in this particular regard, through the successive drafts which culminated in the 1976 Copyright Act. Indeed, the language of what would become section 505 was unchanged after 1964. And neither the House Report nor the Senate Report on the final legislation contains any substantive discussion of the provision.

3. Thus, having noted the various cases ascribing different purposes to section 505, Professor Goldstein concludes that "in exercising their discretion to award attorney's fees, courts should weigh all factors . . that bear on the relevant statutory purposes." Paul Goldstein, 2 Copyright $\S 12.3 .2 .2$ at 363 (Little, Brown, 1989). By way of contrast with the catholicity of this approach, the authors of Nimmer on Copyright emphasize the penal function of awards of attorney's fees to the near exclusion of others, concluding that "culpability factors continue to be the touchstone for the award ...." Melville B. Nimmer \& David Nimmer, 3 Nimmer on Copyright § 14.10[D][2] at 14-129 (Matthew Bender, 1991) ("Nimmer on Copyright"). Neither treatise confronts directly either the lack of useful consensus as to the purposes of section 505 , or the tendency of most accounts of those purposes to omit what is arguably the most important of all: the encouragement of litigation that will help to mark out, as clearly as possible, what is-and what is not-within the scope of copyright.

4. Section $\mathbf{5 0 5}$ provides:

In any action under this title, the court in its discretion may allow the recovery of full costs by or against any party other than the United States or any officer thereof. Except as otherwise provided by this title, the court may also award a reasonable attorney's fee to the prevailing party as part of the costs.

17 USC $\S 505$ (1989). 
use of material from the work, and believes that this use was legally justified. ${ }^{5}$ In constructing my paradigm, I will also make a further assumption: that a lawsuit has been threatened or actually initiated by the copyright owner. The question of how knowledge of section 505 might affect the defendant's (or prospective defendant's) behavior ${ }^{6}$ at this point may be usefully recast as follows: how should a prudent lawyer advise a client in this position, having first determined that there is merit, but no certainty of success, in the defenses available? 7

Once the general character of the law of section 505 is explained, the client is likely to put a two-fold question: what are the probabilities that, in the event of an unsuccessful defense, attorney's fees will be awarded to the plaintiff, and what are the contrasting probabilities that, should the defense succeed, the client may itself be the beneficiary of such an award? To the extent that an analysis of the present state of the law requires the answer that the first set of probabilities is relatively high, and the second relatively low, the client is likely to be discouraged from proceeding. And despite the neutral-seeming language of the statute, which refers only to awards in favor of "prevailing" parties, ${ }^{8}$ examination of the present state of the case law does

5. Obviously, there are several decision points in the prehistory of a copyright case, and the conduct of would-be or actual users of purportedly copyrighted works at any of these points may be affected by the law of attorney's fees. Consider the case of a would-be user who is well aware that a given work is the subject of an asserted copyright, and that its proposed unauthorized use of that work would be strongly objected to by the proprietor of that right. Such a defendant-in-the-making nonetheless may believe (correctly or not) that it is entitled to proceed-perhaps having taken legal advice, or perhaps relying on accumulated trade expertise (not always the most reliable guide in copyright matters). At this point, a sophisticated and well-informed prospective user's choice to act or not to act on this belief might (at least in theory) be influenced by knowledge of the law of $\$ 505$. However, in practice, such knowledge may not be widely disseminated, and in any event, the effect of such knowledge on this underlying conduct is likely to be blurred or diluted by the multitude of other factors that will enter, consciously or unconsciously, into consideration. I will focus, therefore, on the effect of knowledge on the conduct of the user at a later point in the history of this paradigmatic case.

6. At a more general level, common sense suggests that the availability of attorney's fees must affect the behavior of plaintiffs and defendants alike. On the positive side, awards under $\S 505$ can be many times the amount of damage awards to plaintiffs-and they may represent the only chance of a successful defendant to be made financially whole. Although the result obtained in litigation is one factor to be considered in assessing an award of attorney's fees under $\S 505$, the amount of damages recovered need not be a ceiling on such an award. See Rockford Map Publishers, Inc. v Directory Service Co. of Colo., 768 F2d 145, 150 (7th Cir 1985); but see Warner Bros., Inc. v O'Keefe, $468 \mathrm{~F}$ Supp 16 (SD Iowa 1977).

Awards of attorney's fees can represent significant sums. See Cable/Home Communication v Network Productions, 902 F2d 829, 853-54 (1 lth Cir 1990) (sustaining award of $\$ 451,789.06$ to prevailing plaintiff as reasonable exercise of trial judge's discretion, even in the absence of a showing of "bad faith" on the part of defendant).

If a party is partial to risk-taking, or believes strongly that he or she will succeed in litigation, $\S 505$ may act as a spur to litigation on his or her part. More often, where defendants are concerned, the effect will be the opposite.

7. Implicit in this restatement, of course, is the assumption-perhaps open to question-that clients sometimes do comply with the advice of counsel.

8. The question of who qualifies as a "prevailing party" is not free from doubt. See Goldstein, 2 Copyright $\$ 12.3 .2 .1$ at 355-56 (cited in note 3); Nimmer on Copyright $\$ 14.10[\mathrm{~B}]$ at 14-109 (cited in note 3). Often, difficulties arise when a plaintiff, although successful in litigation, has been less than completely successful. But where (for example) the plaintiff has failed to establish any of its central 
yield just such a conclusion: a bias in favor of plaintiffs is clear throughout the decisions, explicit in some and implicit in others.

\section{III}

\section{Atrorney Fee Awards in American Law}

\section{A. The "American Rule"}

In an effort to expose the dilemmas posed by section 505 , it may be helpful to turn first to the general background of American law relating to awards of attorney's fees. But I offer this background with a qualification: it also may be misleading, especially insofar as the goals and purposes of copyright law may diverge from those of other statutory schemes in which awards of attorney's fees are available.

One of the peculiar glories of American common law is the general rule that parties to civil litigation should bear the largest share of their own legal expenses-the fees owed to their respective attorneys-without regard to the outcome of the litigation. ${ }^{9}$ The effect of this rule is to limit the costs of the prosecution or defense of civil actions and, perhaps more importantly, to make those costs easier to predict and control. The existence of the rule, when coupled with the extensive resort to contingency fees so characteristic of American civil practice, probably goes farther than do more elaborate social and cultural exegeses to explain the allegedly characteristic "litigiousness" of our society-that is, the predilection of parties to litigate to a conclusion disputes that might be compromised in another legal system. Assuming some level of "risk averseness" on the part of potential litigants, and some level of uncertainty before the fact of litigation as to its outcome, it follows that the greater the potential financial exposure in the event of an adverse outcome, the less inclined the potential litigants will be to pursue the course of litigation rather than that of compromise. ${ }^{10}$ By limiting the extent of financial exposure for attorney's fees, and by assuring that that which is irreducible will be subject to the parties' control (since it consists of the expenses of their own lawyers), the American rule has the net effect of encouraging litigation.

claims, it is evident that it is the defendant who has prevailed. See Sherry Mfg. Co. $v$ Towel King of Florida, Inc., 822 F2d 1031, 1035 n5 (11th Cir 1987).

9. Alyeska Pipeline Serv. Co. $v$ Wilderness Society, 421 US 240 (1975). Certain exceptions to this rule have been recognized. Courts may award fees "when the interests of justice so require," Hall $v$ Cole, 412 US 1, 5 (1973), or for the "willful disobedience of a court order ... as part of the fine to be levied on the defendant," Toledo Scale Co. v Computing Scale Co., 261 US 399, 426-28 (1923), or when a party has "acted in bad faith, vexatiously, wantonly or for oppressive reasons." F. D. Rich Co. v Industrial Lumber Co., 417 US 116, 129 (1974).

10. See generally A. Mitchell Polinsky, An Introduction to Law and Economics (Little, Brown, 1983). It follows from the same analysis that the less likely a potential party perceives its chances of success in litigation to be, the less inclined it will be (all other things being equal) to run the risk. This elementary deduction will have some significance when the effect of the calculus of copyright attorney's fees on a defendant's motivation to litigate is considered in more detail. 


\section{B. Private Attorneys General}

In the age of statutes, however, there has been considerable legislation in derogation of this general principle. A number of federal statutes authorize federal courts to award attorney's fees to a prevailing party. ${ }^{11}$ The most commonly used of these fee-shifting statutes is the Civil Rights Attorney's Fees Award Act. ${ }^{12}$

Before awarding fees under this act, a court must determine whether the litigant seeking fees is, in fact, a prevailing party. ${ }^{13}$ Once a determination is made that a plaintiff has prevailed, he or she should normally recover attorney's fees unless special circumstances would make such an award unjust. ${ }^{14}$ In striking contrast to the rule favoring awards of attorney's fees for prevailing plaintiffs, prevailing defendants may recover attorney's fees under the act only where the court finds that "the suit was clearly frivolous, vexatious, or brought for harassment purposes." 15 On the whole, the intent and effect of section 1988, and other statutes like it, is clear enough. By empowering particular private individuals to proceed as "private attorneys general," it is aimed at encouraging certain kinds of litigation and, reflexively, discouraging certain sorts of underlying conduct-the violation of the civil rights of individuals.

\section{IV}

\section{Public Interest in Vigorous Defense of Infringement Cases}

Of course, a similar view could be taken, and from time to time has been, of section 505.16 And certainly, it exists in part to encourage the filing of copyright actions, and to discourage infringement itself. But that is not, or

11. See New York State Ass' $n$ for Retarded Children, Inc. v Carey, 711 F2d 1136, 1139 (2d Cir 1983).

12. 42 USC \& 1988 (1989).

13. A defendant may question whether a plaintiff has prevailed on several grounds: (1) the dispute was settled; (2) the defendant has taken some voluntary extrajudicial act that makes the suit moot; (3) the plaintiff prevailed on only some, not all, claims; (4) the plaintiff prevailed only at an interlocutory stage and not fully on the merits; and (5) the defendant itself has prevailed.

14. Newman v Piggie Park Enterprises, Inc., 390 US 400, 402 (1968), construing 42 USC $\$ 2000 a-$ 3(b) (1989), the attorney fee provision of the Public Accommodations Subchapter. Citing such "special circumstances," the Ninth Circuit has denied fees where the plaintiffs were awarded damages that "were not 'modest in relation to the time, effort and skill required of counsel'; adequate compensation to counsel was provided from the recovery," Buxton $v$ Patel, 595 F2d 1182 , 1185 (9th Cir 1979), and where the parties entered into a consent decree that the court viewed as a compromise that would be altered by an award of fees. Aho $v$ Clark, 608 F2d 365, 367 (9th Cir 1979). The Fifth Circuit has withheld fees where the plaintiffs achieved the benefits sought but their suit did not contribute to achieving those results. Riddell $v$ National Democratic Party, 624 F2d 539, 544-45 (5th Cir 1980).

15. Lopez v Aransas County School Dist., 570 F2d 541, 545 (5th Cir 1978).

16. See for example, Roulo v Russ Berrie E Co., 886 F2d 931, 942 (7th Cir 1989); Roth v Pritikin, 787 F2d 54, 57 (2d Cir 1986); and, especially, Diamond v Am-Law Publishing Corp., 745 F2d 142, 148 (2d Cir 1984). Nor is are such justifications of attorney's fees confined to the courts of appeals. See, for example, $A$ E $N$ Music Corp. v Venezia, 733 F Supp 955, 959 (ED Pa 1990). But see Cohen v Virginia Elec. E' Power Co., 617 F Supp 619 (D Va 1985), aff'd, 788 F2d 247 (4th Cir 1986) (distinguishing attorney's fees under Civil Rights Acts, on grounds that legislative history of Copyright Act does not indicate any congressional disposition to limit attorney's fees to defendants). 
should not be, the whole story. ${ }^{17}$ In many of the areas of law where the possibility of awards of attorney's fees is provided for by statute, there is no significant public interest to be balanced against that represented by the private plaintiff in civil litigation. There is, for example, no public interest in encouraging any level of discrimination based on race, gender, or ethnic origin. But copyright is another matter. In copyright, there is strong countervailing interest in seeing that members of the public be allowed to make all legally allowable use of works of creativity-and thus that the outer contours of copyright law be demarcated with as much clarity as possible. The process of demarcation occurs, in most cases, only through repeated litigation of difficult issues.

Vigorous, persistent assertion of defenses to claims of infringement is part of the life blood of our copyright system. To the extent that the rules of the game of copyright litigation, including section 505 , tend to discourage the assertion and litigation of meritorious defenses, the resulting tendency toward the settlement will produce, inevitably, a kind of systemic anemia. Settlements, whatever their value to the immediate parties, do not benefit the public at large by helping to mark out the outer contours of copyright protection; indeed, the practical effect of some settlements may be to suggest that those contours are more generous than is in fact the case. ${ }^{18}$

17. Roth $v$ Pritikin, for example, identifies the purpose of the Copyright Act as being "to encourage suits to redress copyright infringement," 787 F2d at 57, and reasons from this premise that attorney's fees should be more generally available to successful plaintiffs than to successful defendants. In one respect, the methodology of this decision cannot be faulted: absent some clear statement of the legislative purpose attaching to a particular provision of a complex statute, it is necessary in applying that provision to fall back on what one knows of the general purpose of the statutory scheme as a whole. See generally Jim Evans, Statutory Interpretation: Problems of Communication 49-71 (Oxford U Press, 1988). The problem lies in the decision's over-narrow identification of the purposes of the copyright system, which fails to take account of its ultimate, public goal-the promotion of the public interest in access to works of the imagination.

18. Plaintiffs often initiate copyright litigation in a self-generated glare of publicity, a fact to which the pages of any entertainment industry trade journal, such as Variety, or any daily newspaper's "lifestyle" pages, are sufficient testimony. Likewise, the preliminary stages of copyright litigation, including proceedings related to interim injunctive relief (where the standard of proof applied to a plaintiff's case necessarily is lower than that applied at a trial on the merits), are widely reportedwithin the legal profession and beyond. But settlements tend to be private affairs, and a term common to many settlement agreements bars parties from entering into public discussion of their contents. Thus, even a case terminated by settlement may leave behind the impression that the plaintiff's legal theory somehow was vindicated.

A recent instance of this dynamic at work can be found in the history of West Publishing Co. v Mead Data Central, Inc., 799 F2d 1219 (8th Cir 1986). Claiming a copyright interest in the page numeration of the volumes in its National Reporter Series ("NRS"), the plaintiff company sued to prevent the defendant from incorporating those numbers into the "on-line" data provided through its LEXIS system for "computer aided legal research." Id at 1221-22. After the trial court's grant of a preliminary injunction was sustained on appeal, the case went to trial on the merits. After the conclusion of the trial, but before any decision was rendered, the parties announced a settlement (on undisclosed terms), and the complaint was withdrawn. The West NRS page numbers since have begun to appear on LEXIS screens, but the only reported decisions in the case (especially the arguably over-elaborate opinion on the appeal of the preliminary injunction) give the impression that the rationale of West's claim had been thoroughly tested in the crucible of judicial scrutiny. Were it not for the Supreme Court's recent decision in Feist Publications, Inc. v Rural Telephone Service Co., $111 \mathrm{~S}$ Ct 1282 (1991), which casts considerable doubt on that rationale, these "precedents" might have continued to shape copyright doctrine-despite the outcome of the case itself. See generally L. Ray 
I began to think in a sustained way about copyright attorney's fees only when I finally was compelled to do so-to be precise, in May 1990, when I was invited to testify before Chairman Kastenmeier's House Judiciary Subcommittee on Courts, Intellectual Property, and the Administration of Justice on HR 671, which proposed amending section 505 to make the award of attorney's fees mandatory in favor of prevailing plaintiffs qualifying as "small businesses." 19 On behalf of the Educators" Ad Hoc Committee on Copyright Law, ${ }^{20}$ I joined Alfred Sumberg of the American Association of University Professors to speak in opposition to the bill, which ultimately was not reported out of the subcommittee. ${ }^{21}$ But for me, the occasion had a significance beyond the outcome of the hearing or the pleasure I experienced from appearing before the subcommittee: in preparing for my appearance, I was stimulated to think back to how, at the last class session of his Copyright course, Benjamin Kaplan expressed the hope that some of those in the room would practice in the field of copyright, and that, of those who did, not all would represent only copyright owners. I think it's a fair guess that at the

Patterson \& Craig Joyce, Monopolizing the Law: The Scope of Copyright Protection for Law Reports and Statutory Compilations, 36 UCLA L Rev 719 (1989).

19. A "small business" was defined in the bill as one whose number of employees, including those of its affiliates, does not exceed five hundred. See Copyright Infringement Remedies and Nursing Home/Vidocassette Copyright, Hearing before the Subcommittee on Courts, Intellectual Property, and the Administration of Justice of the House Judiciary Committee, 101 st Cong, 2d Sess 3 (1990) ("HR 671 Hearing"). Other features of the proposed legislation included a limited exemption for non-profit educational instutitions, libraries, archives, and public broadcasters. Id.

20. I should emphasize here that in speaking for the Committee, I was substituting, however inadequately, for its Chairman and usual spokesperson, August Steinhilber. The written testimony we submitted for the hearings on HR 671 was (in every sense) a work of "joint authorship," and in drawing on that testimony for this article, I acknowledge the role of Mr. Steinhilber and his staff in preparing it.

21. This is not to say that my opposition, or that of the Ad Hoc Committee on Copyright Law, necessarily was determinative. Notably, the Register of Copyrights also testified unfavorably on HR 671. See HR 671 Hearing at 73-74 (cited in note 19). Although the proposed legislation failed, the underlying problem that it sought to address seemed to be a real, and even pressing, one. Its enactment was being urged primarily by producers of training films (members of the Media Training Association) who market their products (typically in the form of video cassettes) to small numbers of purchasers at relatively high prices. These producers complained that although their products were subject to widespread piracy (especially on the part of customers who ordered one copy of a cassette and proceeded to reproduce several others from it), they were being discouraged from pursuing legal remedies because -in a situation where only small awards of actual or statutory damages could be anticipated from individual defendants-they felt that they could not be sure of receiving adequate awards of attorney's fees even were they to prevail.

In the course of the hearing on HR 671, it developed that the educational audiovisual producers' concerns had more to do with how awards of attorney's fees were calculated than with when such awards were made. Although the representatives of the industry could cite examples of cases in which fee awards had been inadequate to compensate prevailing plaintiffs realistically for the expenses they had incurred, they could not point to any instance in which judicial discretion had been exercised to deny such an award altogether.

Although the calculation of awards of attorney's fees lies outside the scope of this article, it may not be out of order to suggest a possible solution to the legitimate concerns which gave rise to HR 671. This might take the form of legislation designed to channel the exercise of judicial discretion by specifying factors to be considered in deciding the amount of an award of attorney's fees. Such a list, of course, might take into account explicitly the relevant economic circumstances of the prevailing party. For the factors actually considered by courts in making assessment, see Goldstein, 2 Copyright $\S$ 12.3.2.3 at $364 \mathrm{n} 52$ (cited in note 3); Nimmer on Copyright $\$ 14.10[\mathrm{C}]$ at $14-117$ (cited in note 3). 
time, few of Professor Kaplan's listeners had much of an idea what he might be driving at.

I suspect now that behind Professor Kaplan's enigmatic words was the notion that American copyright functions as (among other things) the law of limitations on the assertion of proprietors' interests ${ }^{22}$-and the conviction that unless defendants have both the will to litigate and the lawyers to represent them, that function will be at risk. Indeed, I suspect that we have arrived at a point where the law of attorney's fees operates to sap defendants'

22. It may appear paradoxical-or merely tautological-to describe the statute which conventionally is considered the source of proprietor's rights in Anglo-American copyright, Twentieth Century Music Corp. $v$ Aiken, 422 US 151, 154-55 (1975), as the locus of limitations on those rights. In fact, the proposition is anything but a self-confounding or circular one. From its inception American copyright law has been shaped, in part, by a widely shared (although far from universal) belief that creative persons are inherently entitled to some legal stake in their creations, and that the function of statutory copyright is to "confirm" these rights (in the terminology of US Const, Art I, $\S 1, \mathrm{cl} 1$ ). Although the view never has enjoyed the specific endorsement of the U.S. Supreme Court, the history of American copyright, from its beginnings to the present day, has been marked by the periodic recurrence of such natural rights thinking. See Peter Jaszi, Towards a Theory of Copyright: The Metamorphoses of "Authorship," 1991 Duke L J 455; Craig Joyce, William Patry, Marshall Leaffer \& Peter Jaszi, Copyright Law 15-17 (Matthew Bender, 2d ed 1991). And there is every reason to think that, in the aftermath of U.S. adherence to the Berne Convention, see Berne Convention for the Protection of Literary and Artistic Works in 1989, Berne Convention Implementation Act, Pub L No 100-568, 102 Stat 2853 (1988) (The Berne Convention for the Protection of Literary and Artistic Works (Paris Text-1971) is reproduced in 4 Nimmer on Copyright App 27 (cited in note 3)), this strand (which is dominant in the theory of literary property in many other countries, see, for example, Bernard Edelman, La Propriete Litteraire et Artistique 42-43 (Presses Universitaires de France, 1989)), will become more important in American copyright thought. See Peter Jaszi, A Garland of Reflections on Three International Copyright Topics, 8 Cardozo Arts \& Ent L J 47, 59-61 (1989). The expansive pressure that this development will entail should lend new importance to the notion of statutory copyright as a source of constraint on proprietors' interests.

That notion, in turn, is one of considerable historicity, firmly rooted in the American experience of intellectual property and in American values of free expression. When the Supreme Court in Aiken opined that "[c]reative work is to be encouraged and rewarded, but private motivation must ultimately serve the cause of promoting [its] broad public availability . . ," 422 US at 156, it was invoking this idea. Indeed, the notion of copyright as a constraint on proprietary interests dates back at least as far as Donaldson $v$ Becket, 98 Eng Rep 257, 4 Burr 2408 (HL 1774), a case widely understood as holding that the first copyright statute, the English Statute of Anne of 1710, had placed a durational limit on authors' previously perpetual "common law" rights. For a modern, alternative reading of the case, see Howard B. Abrams, The Historic Foundation of American Copyright Law: Exploding the Myth of Common Law Copyright, 29 Wayne L Rev $1119,1156-71$ (1983).

In this connection, it is important to note $L$. Ray Patterson's argument that, from its origins, copyright has had a "regulatory" concept, functioning to protect "the distributed work against predatory competition," see L. Ray Patterson, Free Speech and Copyright, 40 Vand L Rev 1, 7 (1987), rather than a "proprietary" one. Viewed in this light, the many copyright doctrines that restrict the scope of proprietary rights-such as the idea/expression dichotomy, the bar on protection for "useful articles," and the requirement of "substantial similarity" in the proof of infringement-are anything but anomalies. Rather, they are essential to the scheme of the copyright law as a whole, "defin[ing] the scope of the limited monopoly that should be granted a creator in order to give the public appropriate access to the creation." Id at $7 \mathrm{n} 18$, quoting HR Rep No 781, 98th Cong, 2d Sess 4 (1984). For another significant articulation of the notion that the law must strive to define the limits of the copyright monopoly (and of intellectual property law as a whole), see generally Robert W. Kastenmeier \& Michael J. Remington, The Semiconductor Chip Protection Act of 1984: A Swamp or Firm Ground?, 70 Minn L Rev 417, 440-42 (1985). 
will to litigate, and are already in the process of jettisoning the historic constraining role of copyright doctrine. ${ }^{23}$

The vector of modern American copyright doctrine toward providing protection to more kinds of works, for longer periods of time, against more forms of unauthorized use, ${ }^{24}$ can be traced in the successive revisions of title 17. But it is even more palpable in the copyright case law, for it is in the courts that the unrelenting pressure of market forces for the expansion of proprietors' interests (at the expense of those of users) usually is felt in the first instance. Recent case law illustrates this generalization amply-an outstanding set of examples can be found in the saga of the extension of copyright protection to computer software through a series of developments in which legislation played only a minor role. ${ }^{25}$

Likewise, it is in the record of judicial decisions, more than that of legislation, that we find historical and contemporary instances in which the sometimes seemingly inexorable march of copyright has been at least temporarily arrested. Feist Publications, Inc. v. Rural Telephone Service Co. ${ }^{26}$ the Supreme Court's most recent venture into copyright jurisprudence, isliterally-a case in point. In the face of a widespread belief that at least some degree of copyright protection was available for useful, laboriously-compiled amalgamation of public domain data ${ }^{27}$ (such as the telephone "white pages"

23. Copyright (like other bodies of intellectual property law) must play a constraining function if the "public domain" is to be preserved as a nurturing "commons" available to all. Thus, David Lange has written of the importance of two "fundamental principles":

One is that intellectual property theory must always accept something akin to a "no-man's land" at the boundaries; doubtful cases of infringement ought always to be resolved in favor of the defendant. The other is that no exclusive interest should ever have affirmative recognition unless its conceptual opposite is also recognized. Each right ought to be marked off clearly against the public domain.

David Lange, Recognizing the Public Domain, 44 L \& Contemp Probs 147, 150 (Autumn 1981) (citations omitted). See also id at $150 \mathrm{n} 20$. And see generally L. Ray Patterson \& Stanley W. Lindberg, The Nature of Copyright: $A$ Law of Users' Rights (U Georgia Press, 1991).

It may be unnecessary to resurvey here the reasons why it is important to limit the incursions of proprietary interest into the traditional terrain of the "public domain." In constitutional and historical terms, the notion of a "public domain" is rooted in the ultimate instrumental purpose of the copyright system: the encouragement of creativity and of the dissemination of creative productions. See generally Jessica Litman, The Public Domain, 39 Emory L J 965 (1990) (containing a full exposition of arguments for maintenance of "public domain").

24. See Joyce, et al, Copyright Law at 10-14 (cited in note 22).

25. The enactment in 1980 of present $\$ 118$ of the Copyright Act, which replaced the 1976 version of that section, may have been a necessary condition to the development of software copyright, but it hardly was a sufficient one. Although the act was amended to include a definition of "computer program" in $\$ 101$, programs were not incorporated into the $\$ 102$ itemization of copyrightable subject matter, as such. Instead, in a series of decisions culminating (at least for now) in Apple Computer, Inc. v Franklin Computer Corp., 714 F2d 1240 (3d Cir 1983) and Whelan Associates, Inc. $v$ Jaslow Dental Laboratory, Inc., 797 F2d 1222 (3d Cir 1986), the courts accepted the repeated invitations of the software industry to define its stock in trade as a form of "literary work" and to afford it copyright protection of appropriately broad scope. See Joyce, et al, Copyright Law at 137-42 (cited in note 22).

26. 111 S Ct 1282 (1991).

27. See, for example, the discussion in Jane C. Ginsburg, Creation and Commercial Value: Copyright Protection for Works of Information, 90 Colum L Rev 1865 (1990), which reviews the history of the issue down to the eve of Feist, and Robert C. Denicola, Copyright in Collections of Facts: $A$ Theory for the Protection of Nonfiction Literary Works, 81 Colum L Rev 516 (1981). 
volume actually involved in the litigation), the Court confounded the expectations of most observers by ruling that in fact no such protection was constitutionally permissible. ${ }^{28}$

Feist was, of course, a decision of the court of last resort in copyright cases, reversing a court of appeals decision that itself confirmed the logic of a district court. Often, in fact, defenses that call into question the legal propriety of expanded visions of copyright protection will be vindicated, if at all, only in the latter stages of protracted litigation, ${ }^{29}$ or after they have been repeatedly invoked, without initial success, by many litigants. ${ }^{30}$

The implementation of section 505 has not been neutral despite the neutral-seeming language of the statute. Pro-plaintiff bias appears explicitly in some court decisions and is implicit in others.

28. The potential importance of the unanimous decision, in its confirmation of the vitality of some of the traditional values constraining the indefinite extension of copyright protection, hardly can be overstated. The Court's conclusions that the alphabetically organized "white pages" are not entitled to copyright because the arrangement of the data lacks the talismanic ingredient of "originality," and because the methods by which the data was gathered for inclusion do not display "the modicum of creativity necessary to transform mere selection into copyrightability expression," $111 \mathrm{~S} \mathrm{Ct}$ at 1296, has obvious implications beyond the domain of telephone directories, in particular, or that of factual compilations, in general. Thus, for example, the logic of Feist may require us to reconsider the outcome of many cases that form part of the so-called "second-generation" of decisions relating to computer software copyright. See Joyce, et al, Copyright Law at 137-43 (cited in note 22).

29. Perhaps the most obvious illustration of this premise is the famous "Betamax" litigation, which consumed eight years from its inception to the Supreme Court's final vindication of the principle of "fair use." See Sony Corp. v Universal Studios, Inc., 464 US 417 (1984); see generally James Lardner, Fast Forward: Hollywood, the Japanese, and the Onslaught of the VCR (W.W. Norton, 1987).

30. An example of this latter trend may be taking shape in the Second Circuit, in connection with the much-debated issue of the applicability of the "fair use" defense to quotations from "unpublished" letters, diaries, and other materials. Though the circuit has set its face squarely against the invocation of the defense in such cases, in Salinger $v$ Random House, 811 F2d 90 (2d Cir 1986), and especially New Era Publications Int'l v Henry Holt $\mathcal{E}^{\circ} \mathrm{Co}$, Inc., 873 F2d 576 (2d Cir 1989), cert denied 494 US 1094 (1990), individual judges in the circuit (through their extrajudicial writings) recently have suggested that a reconsideration of this categorical rejection of fair use is underway. See, for example, Jon Newman, Not the End of History: The Second Circuit Struggles with Fair Use, $37 \mathrm{~J}$ Copyright Soc'y USA 12 (1989); James Oakes, Copyrights and Copyremedies: Unfair Use and Injunctions, $38 \mathrm{~J}$ Copyright Soc'y USA 68, 76-82 (1990). That there may be a straw of change in the wind is evident in the recent Second Circuit decision in Wright $v$ Warner Books, Inc., 953 F2d 731 (2d Cir 1991), holding that the defendant's "sparing" quotations and paraphrases of a deceased author's unpublished letters and diagrams was, on balance, "fair use." The precedential value of the decision may be undercut, however, by its adoption of the contention that some of the unpublished journal entries in question were not copyrightable "expression" because they did not "adapt [the authors'] creative style." It remains to be seen whether this may not carry the new emphasis on substantive assessment of "originality," evident in Feist, too far.

It looks increasingly as if any change in the law of "fair use" of unpublished works may have to come from the courts. After a hopeful start, legislation designed to accomplish this result, see $S$ 1035 (Title 1) and Internal Revenue Code of 1986 Amendment, HR 2372, 102d Cong, 1st Sess (1991), now appears to have bogged down. Although the legislation passed the Senate on September 27, 1991, the fair use title was dropped from the substitute version of HR 2372 in the House of Representatives.

If the Second Circuit does "come around" on this issue, at least part of the way, it will set some sort of a new record for speed. It is instructive-and indeed sobering-to remember that it took the Supreme Court 69 years to come to the conclusion (as it ultimately did in Feist) that the court that decided Jeweler's Circular Publishing Co. $v$ Keystone Publishing Co., 281 F 83 (2d Cir 1922) had "misunderstood the statute" when it extended copyright protection to unoriginal factual compilations. Feist, $111 \mathrm{~S} \mathrm{Ct}$ at 1291. 
In the line of decisions originating in the Second and Ninth Circuits, perhaps best exemplified by Diamond $v$. Am-Law Publishing Corp., ${ }^{31}$ bias for plaintiffs is an article of faith, flowing from a straightforward but questionable characterization of copyright as a statutory scheme solely intended to discourage infringement. The cases in this sequence stand for the twin propositions (highly discouraging from the defendant's point of view) that awards to prevailing plaintiffs should be considered routine, ${ }^{32}$ and those to successful defendants exceptional. In particular, these cases suggest that defendants should be afforded attorney's fees only in the event of a showing of "bad faith," on the plaintiff's part, ${ }^{33}$ and that bad faith in turn, must be something more than a mere mistaken belief in the correctness of the plaintiff's position. ${ }^{34}$

31. 745 F2d 142 (2d Cir 1984). Nor is this approach confined to the Second and Ninth Circuits. See also Quinto v Legal Times of Washington, Inc., 511 F Supp 579, 581 (DDC 1981):

[a]n award of attorney's fees ... also prevents copyright infringements from going unchallenged where the commercial value of the infringed work is small and there is no economic incentive to challenge an infringement through expensive litigation.... In addition, an award of attorney's fees serves to penalize the losing party as well as to compensate the prevailing party.

An excellent review of the case law can be found in Elden Dale Golden, The Discretionary Award of Attomey's Fees under the Copyright Act, 13 Hastings Comm/Ent LJ 411 (1991). Unfortunately, I did not have the benefit of that review in preparing this article.

32. See Oboler v Goldin, 714 F2d 211, 213 (2d Cir 1983); Whimsicality, Inc. v Rubies Costume Co. Inc., 891 F2d 452, 457 (2d Cir 1989) ("Plaintiffs who prevail are awarded fees as a matter of course."). A recent example is to be found in Basic Books, Inc. $v$ Kinko's Graphics Corp., 758 F Supp 1522 (SDNY 1991), where the Second Circuit cases, including Diamond, are reviewed, and Nimmer is cited for the proposition that " "the mere fact that the plaintiff has won at trial . . establishes a blameworthiness of sorts on the defendant's part." Id at 1547, quoting Nimmer on Copyright $\$ 14.10$ [D][2] at 14-129 (cited in note 3 ).

33. See, for example, Bibbero Systems, Inc. v Colwell Systems, Inc., 893 F2d 1104, 1109 (9th Cir 1990):

Colwell suggests that we not require a showing of frivolousness or bad faith where a defendant prevails on summary judgment that the claimed copyright is invalid as a matter of law. As Colwell notes, one purpose of section 505 is to encourage plaintiffs to assert colorable copyright claims and to deter infringement. [Citing Diamond v. Am-Law Publishing] This purpose could be undermined by the adoption of Colwell's suggestion.

Notably, this restrictive approach to attorney's fee awards to prevailing defendants appears to be spreading beyond the circuits in which it originated. See Video Views, Inc. v Studio 21, Ltd., 925 F2d 1010,1022 (7th Cir 1991) (requiring showing that action was brought in bad faith or was frivolous); Flag Fables, Inc. v Jean Ann's Country Flags and Crafts, Inc., 753 F Supp 1007, 1017 (D Mass 1990) (adopting "bad faith rule"); see also Hartman v Hallmark Cards, Inc., 833 F2d 117, 123 (8th Cir 1987) (while failing to adopt a "definitive standard" for awards of attorney's fees, court notes that nonprevailing plaintiff did not act "in bad faith and ... her complaint was colorable and not baseless").

34. Formulations of tests for what constitutes "bad faith" on the part of a non-prevailing copyright plaintiff abound: a claim is made in "bad faith" when it is "objectively without arguable merit," Diamond, 745 F2d at 148; "when it rested on "patently erroneous" and "ridiculous" comparisons between the works involved in suit, Bumett v Lambino, 206 F Supp 517, 519 (SDNY 1962), or even when the plaintiff is found to have rejected a "reasonable" settlement offer. See, for example, Shapiro, Bernstein E Co. v 4636 S. Vermont Ave., Inc., 367 F2d 236, 243 (9th Cir 1966).

All of these formulations have at least two characteristics in common, however. First, they focus exclusively on the plaintiff's conduct in connection with the litigation, rather than on any precedent extrajudicial activities; in this, they are unlike the standards applied to assess the defendant's "bad faith," which take conduct in the period prior to litigation into account. Second, they define criteria that will be, as a practical matter, difficult to satisfy in most cases. See note 39 . 
More recently the Ninth Circuit has taken a less skewed approach to attorney's fees. It is asserted that a showing of bad faith should be, and generally is, the essential prerequisite for an award to either a prevailing plaintiff or a prevailing defendant. A number of decisions have suggested that a finding of fault on the part of the non-prevailing party is a prerequisite to the award of attorney's fees. ${ }^{35}$ In particular, the discussion of attorney's fees in the influential treatise Nimmer on Copyright is organized into an argument that, in theory and practice, "culpability" is the "decisive factor in determining whether to impose attorney's fees." 36

On its face, this approach may seem to promote the goal of neutrality in the application of section 505. In fact, however, it tends to cut as strongly - or almost as strongly-against defendants as does the overtly biased approach outlined above. The problem arises, in part, because, while the inquiry into a non-prevailing plaintiff's culpability goes solely to the conduct of the litigation, the parallel inquiry concerning a non-prevailing defendant emphasizes, in addition or in the alternative, the underlying infringing activities. Culpability thus will be more or less routinely present in the case of the paradigmatic copyright defendant whose legal situation was outlined above, who is found to have made unauthorized, infringing use of a work in which (as that defendant was aware) copyright has been claimed. ${ }^{37}$ By contrast, culpability will likely not be found in the case of the plaintiff who has

35. See, for example, Cooling Systems and Flexibles, Inc. v Stuart Radiator, Inc., 777 F2d 485, 493 (9th Cir 1985).

36. Nimmer on Copyright $\$ 14.10[\mathrm{D}][1]$ at 14-122 (cited in note 3). The treatise treats "culpability" as a somewhat broader category than "bad faith":

[ $t$ ] hus, for example, attorney's fees have been awarded where the losing party has pursued the action in bad faith, or where he conducted the litigation in a manner calculated to delay hearing on the merits and to increase the opposing party's costs, or where he had no reasonable grounds for assuming the position taken in the action. It has even been held that attorney's fees are justified by reason of the losing party's refusal during the pendency of the action to either make or accept a reasonable offer of settlement.

Id § 14.10[D][1] at 14-119-20. But the distinction between "bad faith" and "culpability" seems more semantic than real. In other discussions, delaying tactics, failure to assert a colorable claim, and refusal to settle have been considered elements going to the showing of "bad faith."

The treatise further suggests that, in effect, all judicially-articulated standards for deciding the question of whether to award attorney's fees are "fault-based," including those which overtly disclaim such a basis. Id $\$ 14.10[D][2]$ at 14-129. See note 42 and accompanying text, discussing "even-handed," multifactor approaches.

37. Another way of putting the point is that in the case of this paradigmatic-and typicalcopyright defendant, "bad faith" will be presumed in the event that his or her legal defenses fail to carry the day. Cases demonstrating this proposition are collected in Goldstein, 2 Copyright $\$ 1$ 2.3.2.2(a) n29 at 357 (cited in note 3). See, for example, Lauratex Textile Corp. v Allton Knitting Mills, Inc., 517 F Supp 900, 904 (SDNY 1981); Boz Scaggs Music v KND Corp., 491 F Supp 908, 915 (D Conn 1980); BËB Auto Supply, Inc. v Plesser, 205 F Supp 36,41 (SDNY 1962). The point is perhaps most poignantly illustrated by those cases in which-exceptionally-attorney's fees are not awarded to a prevailing plaintiff, even though the defendant acted with knowledge of the plaintiff's copyright. See, for example, National Broadcasting Co. $v$ Sonneborn, 630 F Supp 524, 542 (D Conn 1985) (finding that defendant's reliance on a copyright search was a "good faith" act). The same focus on defendants' pre-litigation activities is reflected in Whelan Associates, Inc. v Jaslow Dental Laboratory, Inc., 609 F Supp 1325, 1329-30 (ED Pa 1985) (denying attorney's fees because defendants had relied on competent legal advice), aff'd, 797 F2d 1222 (3d Cir 1986), cert denied, 479 US 1031 (1987); and Baldwin Cooke Co. v Keith Clark, Inc., 420 F Supp 404, 409 (ND Ill 1976) (holding that reliance on 
vigorously, although erroneously, pressed a legally flawed claim without ultimate success. In such instances, to quote Professor Goldstein, "the courts have found that a plaintiff did not act in bad faith when, though his claim was meritless and bordered on the unreasonable, it was neither frivolous nor subjectively brought in bad faith." 38 In effect, two different standards are being employed to ascertain culpability: an objective standard, directed to pre-litigation conduct, in the case of unsuccessful defendants, ${ }^{39}$ and a subjective one, focusing on motivation, in the case of unsuccessful plaintiffs.

This disparity in approach extends to the evaluation of other potential indicia of culpability, such as a non-prevailing party's refusal to settle litigation, either by offering settlement, or accepting a reasonable offer made by an opponent. Assuming a defendant has a defense that is potentially meritorious but, when evaluated in prospect, uncertain of success, a plaintiff's refusal to settle is likely to be viewed as natural and defensible. Indeed, viewed in the light of the presumed purpose of the statute to encourage litigation to vindicate copyright, that refusal even may appear salutary. In any event, evidence of "bad" subjective motivation is likely to be difficult to come by, whereas the defendant's refusal to settle, in itself, may be seen as indicative of fault ${ }^{40}$ Obviously, the existence of such a disparity in approach could operate with well-informed defendants as a powerful incentive to settle cases brought against them rather than to litigate these to a conclusion. ${ }^{41}$

If it is relatively evident that approaches to the assessment of attorney's fees based on culpability or bad faith fall short, in practice, of the goal of neutrality, it is more difficult to assess how far systemic bias is avoided in the so-called "even-handed approach" to discretionary awards of attorney's fees under section 505, typified by Lieb v. Topstone Industries, Inc. ${ }^{42}$ In some

advice of counsel did not vitiate defendant's "willfulness" for purposes of a determination of attorney's fees).

In other copyright contexts, such as the law of statutory damages under 17 USC $\S 504$ (c), "willfulness" often is found simply on the basis that the defendant acted with actual (or even imputed) knowledge of the plaintiff's asserted rights. Much the same approach to the determination of the defendant's "culpability" appears to be at work in the context of $\S 505$ attorney's fees. See Engel v Wild Oats, Inc., 644 F Supp 1089 (SDNY 1986) (applying objective test of "willfulness" to issues of statutory damages and attorney's fees).

38. Goldstein, 2 Copyright $\$ 12.3 .2 .2$ (a) at 361 (cited in note 3) (citing numerous cases).

39. In Boz Scaggs Music, the court stated that "defendants' conduct, whatever their precise state of mind, was certainly not innocent . . . they made no attempt whatsoever to avoid infringement although they were well aware of the law's requirements." 491 F Supp at 915.

40. The dilemma is neatly illustrated by the facts of Goldman-Morgen, Inc. v Dan Brechner $\&$ Co., 411 F Supp 382 (SDNY 1976), where plaintiff had offered $\$ 700$ in settlement and defendant $\$ 315$; after damages of approximately $\$ 3,000$ were assessed, the court also awarded an additional $\$ 4,500$ in attorney's fees.

41. In general, it would appear that plaintiffs have less to lose from taking a hard line on settlement than do defendants. Any refusal to settle may weigh against a defendant in the event that the plaintiff prevails, but the plaintiff's refusal of an offer of settlement will be found justified if the recovery exceeds the amount of the offer. See Quinto, 511 F Supp at 581.

42. 788 F2d 151 (3rd Cir 1986). Nimmer, of course, takes the position that the "even-handed" approach cannot escape the force-field of "culpability"-and that, functionally considered, it represents no real departure from "fault-based" approaches, discussed above. Nimmer on Copyright $\$ 14.10[D][2]$ at 14-126 (cited in note 3). The present discussion, however, assumes that the "evenhanded" approach does represent a significant new development in the application of $\S 505$, and 
respects, the analysis of that decision has much to recommend it-particularly its sensitivity to the possibility that there may be systemic costs to encouraging the prosecution of infringement claims routinely or uncritically. Certainly, the account that emerges of factors to be considered in awards under section 505 seems like a new departure: "frivolousness, motivation, objective unreasonableness (both in the factual and the legal components of the case) and the need in particular circumstances to advance considerations of compensation and deterrence." 43 But there may be less to this new departure than meets the eye. When the Lieb factors are examined individually, a problem appears: rather than providing a means to encourage the assertion and litigation of meritorious defenses, it is all too likely that these factors will be interpreted in a way that reflects copyright business as usual, carrying forward the uncritical bias of other judicial standards for applying section 505, which favors the assertion of claims over the assertion of defenses.

The criterion of frivolousness is, of course, applicable in precept to both plaintiffs and defendants; the question, however, is whether in practice the application of this standard will be even-handed. Consider the case of a plaintiff whose claim involves a novel extension of copyright, and the defendant whose defense is similarly unprecedented. In the unhappy (but by no means unlikely) event that such a claim or defense does not prevail, there may be a far greater risk that, in hindsight, an unsuccessful defense rather than an unsuccessful claim may be deemed to have been frivolous. Passing to the second Lieb factor, it is enough to note again the risk of bias inherent in any standard looking to motivation, already discussed above. ${ }^{44}$ In effect, a double standard may be employed in assessing motivation, looking to objective circumstances of pre-litigation conduct where non-prevailing defendants are concerned, and to the subjective motives underlying the conduct of the litigation itself where the focus is on non-prevailing plaintiffs. Considered in itself, the additional criterion of objective unreasonableness is somewhat difficult to plumb. But insofar as it goes to the conduct of the litigation itself, it would seem difficult to distinguish from the inquiry into

attempts to assess it on its own terms. The attempt, however, runs into the paucity of case law, in the aftermath of Lieb, developing the "even-handed" approach; inevitably, therefore, one is driven back to reading the tea leaves of Lieb itself. See, for example, Original Appalachian Artworks, Inc. v McCall Pattern Co., 825 F2d 355 (11th Cir 1987) (adopting "even-handed" standard and approving trial court's exercise of discretion without detailed analysis); Sherry Mfg. Co. v Towel King of Florida, Inc., 822 F2d at 1034 (11th Cir 1987) (remanding case for new determination on appropriateness of attorney's fees).

My ultimate conclusion, I suspect, is not too different from that expressed in Nimmer on Copyrightthe departure of Lieb from prior precedent is more apparent than real. Where I differ from the analysis of the treatise is in my conviction that an approach to applying $\S 505$ that departs significantly from "fault-based" approaches nonetheless is possible.

43. Lieb, $788 \mathrm{~F} 2 \mathrm{~d}$ at 156 . The listing apparently is designed to be illustrative rather than inclusive; in the opinion, however, no additional factors are suggested.

It is noteworthy that in arriving at its formulation of the standard for the award of attorney's fees, Lieb specifically states that the legislative history of the Copyright Act cannot support a bias in favor of plaintiffs, id at 155, following Cohen v Virginia Electric E Power Co., 617 F Supp at 619 , discussed in note 16.

44. See text accompanying notes 34-38. 
frivolousness, and to the extent that it goes to underlying conduct, it is far more likely to weigh against defendants than plaintiffs. ${ }^{45}$

Finally, and most originally, Lieb counsels courts to consider "compensation and deterrence." Unfortunately, from the perspective of this article, this factor seems to favor plaintiffs in the important sense that it can be invoked more often and more plausibly by prevailing plaintiffs than by prevailing defendants. Breaking this compound factor down into its constituent parts, it appears that if compensation refers to the need to reimburse less well-to-do parties for the costs of litigation itself, that rationale could be adduced to favor awards to either plaintiffs or defendants, turn and turn about. If, however, it refers to the need to compensate successful parties for extra-judicial losses, it will apply, in the usual case, only to plaintiffs. The deterrence of infringement is a rationale available for the award of attorney's fees to any successful plaintiff, at least where the defendant cannot plausibly claim "innocence," while the deterrence of the assertion of harassing or burdensome claims will apply only in a minority of cases where the defendant has been successful-those in which the plaintiff has acted in bad faith.

If encouraging the assertion and litigation of meritorious defenses should be a goal in implementing the scheme of section 505, of co-equal importance with the vindication of copyright claims and the deterrence of infringement, the even-handed approach of Lieb represents some progress over the overtly biased approach that presumes the entitlement of prevailing plaintiffs to attorney's fees, and something of a gain, at least in precept, over the scheme that treats culpability as the precondition for the making of an award. If the preceding analysis is correct, however, an uncritical application of the evenhanded approach is likely to perpetuate, rather than fundamentally alter, the pervasive plaintiff bias of the American law of copyright attorney's fees.

What is required then, is a new departure of at least modest dimensions. ${ }^{46}$ By definition, the "presumptive" approach to awarding attorney's fees is beyond reconstruction; nor is it easy to see how the culpability-based approach advocated in Nimmer on Copyright could be revised to take significantly greater account of the defendant's dilemma. ${ }^{47}$ But the multifactor, even-handed approach of Lieb may be susceptible to judicial refinement, with this end in view. Alternatively, of course, the problem of imbalance could be addressed legislatively, in amendments to section 505 designed to channel the exercise of judicial discretion by specifying factors to be considered in making attorney's fees awards. The effect of such corrective

45. See notes 39-40 and accompanying text

46. This is particularly true because several important decisions recently have expressed indecision over what standard should apply to decisionmaking under $\$ 505$. See, for example, Walt Disney Co. $v$ Powell, 897 F2d 565, 568 (DC Cir 1990).

47. The view that attorney's fees "are the rule" and should be "awarded routinely" to prevailing parties, enunciated in Micromanipulator Co. $v$ Bough, 779 F2d 255, 259 (5th Cir 1985)-where perhaps notably, a plaintiff had prevailed-would address the problem, but only by depriving courts of their discretion to take fully interests implicated in particular cases. See Golden, 13 Hastings Comm/Ent $L \mathrm{~J}$ at 431-32 (cited in note 31 ). 
legislation would be to make clear the importance of the participation by both groups of litigants in the continuing elaboration of American copyright doctrine.

Whatever approach to the reform of the law of attorney's fees is taken, the content of the required change will be essentially the same. The array of factors considered in section 505 must be explicitly supplemented to take account of the important public purpose served by the vigorous defense of copyright cases. By one means or another, the specific character of defenses interposed, successfully or unsuccessfully, in copyright litigation should be given explicit consideration in section 505 determinations, whether the question is to award attorney's fees in favor of a prevailing defendant or against a non-prevailing one. In making these determinations, courts have, will, and always should, consider how far a plaintiff's decision to litigate serves to promote the integrity of the protective scheme created by the copyright statute. But in addition to the other factors that may bear on the propriety of a section 505 award in a given case, courts also should weigh the extent to which the defendant's decision to litigate a case to a conclusion tends to effectuate what I have asserted to be another of the grand objectives of American copyright: the demarcation of the sphere of private right from the public domain. Traditionally, we have been pleased to presume that the vindication of private rights by copyright plaintiffs served a larger public purpose $;^{48}$ in the future, we must afford copyright defendants the benefit of a parallel presumption.

Where applied, such a presumption would cut against the award of attorney's fees to successful plaintiffs, requiring some special, additional showing to justify such awards; and, of course, it would cut in favor of more frequent awards to successful defendants. ${ }^{49}$ Obviously, such a presumption would not attach to defenses asserted in bad faith, as that term has been employed throughout this article. Nor need it apply, at least with equal force, to all meritorious defenses.

In this connection, it may be useful to posit a typology of the copyright defenses that may be asserted, with or without success, in litigation:

\footnotetext{
48. For example, the Quinto court stated: "if the Act were not enforced by private suits, the incentives Congress established to encourage authorship would have little effect. One way Congress sought to ensure that the Copyright Act would be enforced was to provide for discretionary awards of costs and attorney's fees." 511 F Supp at 581 .

49. I have been unable to locate any reliable census of awards of attorney's fees, which might suggest the relative frequency with which section 505 has been invoked successfully by prevailing plaintiffs and defendants, respectively. But there is some suggestive evidence: the survey of the size of attorney's fees awards in Nimmer on Copyright contains almost 93 items, and of these only seven are defendants. See Nimmer on Copyright $\S 14.10[\mathrm{C}]$ at 14-113-16 n19 (cited in note 3).
} 
(a) The first category consists of defenses of potentially general applicability, concerning the copyrightability of the plaintiff's work or the scope of protection for that work, that are asserted to counter a novel claim seeking to extend the reach of copyright protection to new subject matter, or to exclude some previously available set of uses. A defense of noncopyrightability interposed in the first case testing the availability of copyright protection for the sequencing of nucleic acids in DNA produced by genetic engineering exemplifies one of the components of the former group..$^{50}$ The argument that the scope of copyright in a published law report should not extend to the details of page numeration is typical of the latter. ${ }^{51}$

(b) Into the second category fall other defenses of potentially general applicability, concerning again either copyrightability of the plaintiff's work, or the question of the scope of protection available for that work, but which, if successful, would operate to restrict broader visions of the coverage of copyright that previously have gained a significant measure of popular acceptance. The defense of non-copyrightability asserted and vindicated in the Feist case provides an outstanding recent example of this category.

(c) This category includes certain defenses of essentially local character-applications of familiar limiting principles in copyright law to the facts of individual cases that focus on the particular character of the works involved in litigation. Some of the defenses characteristic of this category would include lack of substantial similarity, ${ }^{52}$ merger of idea and expression in the plaintiff's work, ${ }^{53}$ and the so-called "useful articles" doctrine. ${ }^{54}$

(d) Here are encompassed other defenses of a local character, invoking alleged non-compliance with the historical and contemporary formal requirements of the copyright systemomission of notice, failure to renew, failure to register, and the like. ${ }^{55}$

50. See Irving Kayton, Copyright in Living Genetically Engineered Works, 50 Geo Wash L Rev 191 (1982).

51. See West Publishing Co. $v$ Mead Data Central, Inc., $799 \mathrm{~F} 2 \mathrm{~d}$ at 1219. As indicated there, this issue was not resolved in the litigation, which was settled without a decision on the merits. When it arises again, it will be, once more, a case of first impression.

52. See, for example, Reyher $v$ Children's Television Workshop, 533 F2d 87, 92 (2d Cir 1976) (finding no infringement in case of children's stories which differed in "total feel").

53. See, for example, Herbert Rosenthal Jewelry Corp. v Kalpakian, 446 F2d 738 (9th Cir 1971).

54. See, for example, Brandir International, Inc. v Cascade Pacific Lumber Co., 834 F2d 1142 (2d Cir 1987).

55. Examples of cases falling into this category are so numerous that they defy exemplary citation. I will make do with one: Epoch Producing Corp. $v$ Killiam Shows, 522 F2d 737 (2d Cir 1975) 
(e) The additional local defenses making up this category are those that go, in one way or another, to copyright ownership, rather than to the existence of a right, its scope, or the limitations upon its exercise. ${ }^{56}$

(f) Finally, this category collects the various defenses based on the doctrine of "fair use," the wild cards of American copyright litigation. The nature of these defenses makes them difficult to characterize, as a group, in terms of generality and localness of application. Of necessity, all invocations of fair use are highly fact specific, ${ }^{57}$ but some (although far from all) are nonetheless of potentially broad precedential importance. ${ }^{58}$

With the singular and significant exception of this final category, the preceding typology represents the various copyright defenses ranged in descending order of systemic significance, when assessed in terms of the goal of effectively policing the outer boundaries of this state-sanctioned network of private monopoly interests. In furtherance of this goal, courts considering section 505 applications made by prevailing defendants or against nonprevailing ones should give particular consideration to the position of the defendant who, successfully or unsuccessfully, has invoked defenses in category (a). Here, it should be stressed that what distinguishes these defenses is not their novelty, as such. ${ }^{59}$ The assertion and litigation of those defenses should be encouraged because clear demarcations in this area are essential to the maintenance of the delicate balance between private right and public interest that should characterize copyright as a whole. Thus, defendants who have prevailed against the odds with arguments of type (b) likewise may be entitled to some compensation for their often significant legal expenses, although those who have stood and fallen on such defenses may not be so well situated to claim relief from awards of attorney's fees against them.

(holding that the motion picture The Birth of a Nation was not protected by copyright, as a result of qualified claimant's failure to renew).

56. Examples in this category include the long line of cases construing the "work for hire" doctrine of American copyright law, including Community for Creative Non-Violence v Reid, 490 US 730 (1989), and-a growing area of litigation-those construing the law of joint authorship. See, for example, Olan Mills, Inc. $v$ Eckerd Drug of Texas, 1989 Copyright L Dec (CCH) ף 26,420 (ND Tex 1989).

57. See generally William Patry, The Fair Use Privilege in Copyright Law (Bureau of Natl Affairs, 1986).

58. See, for example, Fisher $v$ Dees, 794 F2d 432 (9th Cir 1986) (finding fair use in case of song parody). Another good example of the potential generality of "fair use" defenses is provided by the developing line of cases in the Second Circuit, involving the use of "unpublished" materials in historical and biographical writing. See note 30 . Here, it is important to note that, according to the general wisdom of the cases, it is through "fair use"-and only through "fair use"- that the values of free expression in the first amendment operate to constrain the exercise of the copyright monopoly. See New Era Publishing, 873 F2d 576.

59. Nonetheless, the case law giving weight to the "novelty" and "complexity" of the issues in litigation, when declining to award attorney's fees against non-prevailing defendants, may reflect (at least indirectly) the grounds on which this category of defenses has been awarded preeminent position in the typology. See, for example, McCulloch v Albert E. Prince, Inc., 823 F2d 316, 323 (9th Cir 1987). 
Crucial as the assertion of defenses with such great potential importance may be, those who rely on them do so with their eyes open, in full awareness of their uncertain promise.

Although the defenses in category (c), which comprise specific applications of general doctrines limiting the scope of copyright protection, necessarily are less generalizable than those in categories (a) and (b), their routine and vigorous assertion has a systemic importance of its own. Unless litigants believe that they can rely on those limiting doctrines without unreasonable exposure in the event of loss, the resulting trend toward compromise will tend to undermine the integrity of the copyright system as a whole. While courts probably should be conservative in granting section 505 awards to defendants who succeed with defenses in this category, they should be equally wary of the chilling effect that would be generated by routine awards of attorney's fees against defendants who have asserted such defenses unsuccessfully.

Type (d) defenses are characterized by still less generalizability than those of type (c). In addition, although formalities traditionally have been relied upon as an important source of limitations on the reach of the statutory monopoly, contemporary trends in copyright legislation exemplify a clear trend away from such reliance. ${ }^{60}$ With time, the public interest in their assertion will grow more and more attenuated, and it seems both likely and appropriate that courts will decline to give it much, if any, special weight in assessing or refusing to assess attorney's fees under section 505 , at least so long as neither claim nor defense is shown to have been interposed in bad faith. ${ }^{61}$

Much the same can be said of type (e) defenses. Encouraging their assertion by giving defendants who rely on them special consideration in section 505 decisionmaking would contribute little or nothing to the maintenance of the "economy" of copyright, insofar as the demarcation of common intellectual property from individual intellectual property is concerned. ${ }^{62}$

60. See generally Ralph S. Brown, Jr., Publication and Preemption in Copyright Law: Elegiac Reflections on Goldstein v. California, 22 UCLA L Rev 1022 (1975).

61. Where a plaintiff is aware of a formal defect in its copyright claim, but chooses to assert that claim in any event, putting to the defendant the cost of discovering and demonstrating the defect, an award of attorney's fees to that defendant generally will be in order. This is not to say, however, that the unsuccessful assertion of defenses based on formalities should be penalized by means of $\S 505$; so long as works first created or distributed under older copyright regimes exist, defenses based on the technicalities of those statutes will continue to be available and legitimate means for the vindication of defendants' private interests.

62. The generalization just offered is open to question where defenses challenging the application of the "work for hire" doctrine are concerned. Although the judicial elaboration of this doctrine, and of the limitations upon it, plays no role in marking the boundary between private and public interest, it does have another important function. To the extent that the American copyright exists to encourage and reward individual creative efforts, continued close scrutiny of the "work for hire" doctrine assures this function will be fulfilled. Although traditional American copyright doctrine has not favored individual creators over corporate ones, there are indications that the changes in copyright culture in the aftermath of American adherence to the Berne Convention may gradually (or not so gradually) bring the philosophy of our system into closer line with those of the 
Turning to the final category, it is as difficult and perhaps fruitless to generalize about the correct treatment of fair use defenses in section 505 decisionmaking as it is to discuss any other aspect of this particularistic doctrine at the level of generality. On the one hand, the extreme fact specificity of defenses in category ( $f$ ) may render them poor candidates for special consideration with respect to attorney's fees. Moreover, the defense of fair use often is asserted as something of a last resort; although there may be arguable grounds to support it, there usually is no real expectation of success. On the other hand, the assertion of fair use defenses, considered as a class, is crucial to the continuing struggle to impose limits on the marketdriven expansive tendencies of American copyright-and at least some invocations of fair use have obvious potential significance beyond the facts at hand. Ultimately, courts will have to proceed case by case in deciding when and how much special weight to give a prevailing or nonprevailing defendant's invocation of fair use in disposing of post-trial motions for attorney's fees.

\section{ConClusion}

The preceding analysis is designed to suggest how, and to what extent, courts should take account of the importance of promoting the vigorous defense of copyright actions, as well as their vigorous prosecution, in applying section 505. Obviously, adopting the suggestions made here would pose some real problems. Because the weight to be attached to the assertion of a given defense varies according to its category, and even within a given category, according to its particulars, and because federal civil procedure permits the assertion of multiple defenses, cumulatively and in the alternative, judges adopting the techniques of decision recommended here would need to analyze defendants' pleadings and conduct at trial, as well as the outcomes of litigation, in order to determine which defenses were relied upon most strongly. This necessity, however, would impose no significant additional burdens on the courts beyond those already entailed in section 505 decisionmaking. ${ }^{63}$

For those who regard the philosophy of "more is better" with some skepticism, at least where intellectual property law is concerned, Chairman Kastenmeier's depature from the U.S. Congress has both a practical and a symbolic significance, and neither bodes well for the future. Today, copyright law is approaching a crisis, as the pressure to expand its coverage grows ever

continental "authors' rights" countries. See Jaszi, 1991 Duke L J at 496-500 (cited in note 22) (discussing the rise of "moral rights" thinking in the United States).

63. Thus, for example, judges already must sort through the record, in the aftermath of litigation, to determine whether a plaintiff who relied on several distinct claims succeeded on all or only on some, in order to apportion awards of attorney's fees accordingly. See Nimmer on Copyright $\$ 14.10[B]$ at 14-109-10 (cited in note 3) (collecting cases on apportionment in cases involving multicount complaints). 
stronger, and the forces capable of resisting those pressures ever weaker. As technical, and even trivial, as the subject of attorney's fees may seem when viewed from the standpoint of grand theory, section 505 and its proper application are of the greatest practical importance to the actual conduct of copyright litigation, and thus to the vindication of the interests that the American law of copyright is designed to promote. It remains to be seen whether or not legislation will be required to cause courts to appreciate more fully the copyright defendant's dilemma, and to focus more clearly on aspects of the public interest for which the defendant is a proxy, in applying section 505. Finally, then, this article does no more than to propose criteria, supplementary to those now current in section 505 decisionmaking, that could be employed, even in the absence of legislation, to assure that the attorney's fees provision of title 17 is interpreted in light of all the objectives of our copyright system, rather than only some of them. 
